\title{
Schending van de Wet toezicht accountantsorganisaties
}

\section{Rik Roos}

SAMENVATTING Accountantsorganisaties moeten een vastlegging maken als medewerkers de Wet toezicht accountantsorganisaties (Wta) schenden. Deze vastlegging vormt voor de Autoriteit Financiële Markten (AFM) een graadmeter voor de werking van het stelsel van kwaliteitsbeheersing en voor de manier waarop accountantsorganisaties omgaan met overtredingen. Ook vormt deze vastlegging de basis voor een jaarlijks verslag aan medewerkers. Wat komt in het overzicht van schendingen en wat is een mogelijke opvolging?

RELEVANTIE VOOR DE PRAKTIJK De Wta en het Besluit toezicht accountantsorganisaties (Bta) zijn relatief jong. De praktische toepassing en uitwerking zijn niet volledig uitgekristalliseerd, hoewel enige uitleg in de parlementaire geschiedenis is opgenomen en de AFM zich inspant om kaders aan te geven. Dit artikel plaatst schendingen als bedoeld in artikel 24 Bta in perspectief en beoogt daarmee een bijdrage te leveren aan het debat.

\section{Inleiding}

Voorschriften rond schendingen van de Wta vormen een actueel thema. Het betekent voor accountantsorganisaties ${ }^{1}$ dat zij een overzicht moeten bijhouden van schendingen door medewerkers van de bij of krachtens de artikelen 13 tot en met 24 van de Wta gestelde regels (Staatsblad, 2006b, art. 24 lid 1). Deze vastlegging vormt de basis voor het evalueren en opvolgen van schendingen en is onderdeel van het proces van kwaliteitsbewaking bij de uitvoering van bij wettelijke controles. ${ }^{2}$ Het overzicht van schendingen geeft een beeld van de kwaliteit van interne systemen en van het zelfreinigend vermogen van de accountantsorganisatie. Schendingen zullen bijvoorbeeld aanleiding geven tot het herstellen van geconstateerde fouten, het verbeteren van het kwaliteitsbeleid of het ontwikkelen van trainingsmateriaal. Dit helpt de beroepsuitoefening continu te verbeteren. Voorts moeten accountantsorganisaties jaarlijks intern op hoofdlijnen verslag doen van geconstateerde schendingen, van getroffen maatregelen en van de daaraan ten grondslag liggende overwe- gingen (Staatsblad, 2006b, art. 24). Dit verslag is gericht aan medewerkers zodat zij hiervan kunnen leren. Voor beleidsbepalers vormt het verslag een middel om periodiek de waarde van kwaliteit te onderstrepen. Dit is van belang gezien het positieve effect ervan op de interne bedrijfscultuur (International Auditing and Assurance Standards Board (IAASB), 2004, par. 10).

Het schenden van de Wta is een vorm van normoverschrijdend gedrag ${ }^{3}$ en doet afbreuk aan naleving van gedrags- en beroepsregels die zijn opgezet om de kwaliteit bij wettelijke controles te waarborgen. ${ }^{4}$ In de literatuur is regelmatig aandacht besteed aan normoverschrijdend gedrag door accountants. Carcello e.a. (1996) onderzoeken het bestaan van normoverschrijdend gedrag, de mate waarin zich dit voordoet en onder welke omstandigheden. Het merendeel van de respondenten in hun onderzoek blijkt geen ervaring te hebben met normoverschrijdend gedrag. Dit is positief voor het accountantsberoep en sluit aan bij de uitkomsten van onderzoek door Donnelly e.a. (2002, p. 253), die concluderen dat normoverschrijdend gedrag en het tolereren daarvan onder accountants weinig plaatsvindt en een relatief hoge kans heeft ontdekt te worden. Onderzoek van Carcello e.a. ${ }^{5}$ (1996) en van de Public Company Accounting Oversight Board (PCAOB, 2008) illustreert echter dat soms ontoereikende beoordeling plaatsvindt van belangrijke delen uit het controledossier. Otley en Bernard (1996, p. 65) concluderen dat haalbaarheid van het controlebudget een belangrijke invloed heeft op gedrag $^{6}$, evenals de leiderschapsstijl binnen het controleteam. Malone en Roberts (1996) en Donnelly e.a. (2003) evalueren het verband tussen persoonskenmerken en de neiging normoverschrijdend gedrag te tolereren. Malone en Roberts (1996) plaatsen dit in breed perspectief en onderzoeken daarbij tevens de relatie met het kwaliteitsbeleid van de accountantspraktijk, met de praktijkstructuur en met gepercipieerde budgetdruk. Margheim e.a. (2005) en Gundry (2006) leggen eveneens de relatie tussen budgetdruk en normoverschrijdend gedrag.

Dit artikel nu is als volgt opgebouwd. Paragraaf 2 behan- 
delt het begrip schendingen volgens de Wta en beschrijft het onderscheid tussen schendingen, incidenten en overige vormen van normoverschrijdend gedrag. Paragraaf 3 behandelt een aantal mogelijke oorzaken van normoverschrijdend gedrag. Accountantsorganisaties moeten bij schendingen registreren welke aanpassing heeft plaatsgevonden in het stelsel van kwaliteitsbeheersing en welke maatregel het heeft genomen jegens betrokken medewerkers. Paragraaf 4 staat daarom stil bij het evalueren en opvolgen van schendingen. Paragraaf 5 plaatst de voorschriften rond schendingen in internationaal perspectief. Het artikel sluit af met een conclusie.

\section{Normoverschrijdend gedrag, schendingen en incidenten}

\subsection{Normoverschrijdend gedrag}

Gedrag van accountants is normoverschrijdend als dit in wezen of in schijn afbreuk doet aan de kwaliteit van assurance- of daar aan verwante opdrachten. ${ }^{7}$ De Wta maakt een onderscheid tussen de begrippen schendingen, ernstige schendingen en incidenten. Al deze begrippen zien op een vorm van normoverschrijdend gedrag (zie figuur 1).

Veelgenoemde voorbeelden in wetenschappelijk onderzoek van normoverschrijdend gedrag zijn het aftekenen van werkprogramma's zonder deze volledig uit te voeren, het tolereren dat cliënten controlebevindingen gebrekkig verklaren, het volstaan met een oppervlakkige beoordeling van controle-informatie of het onvolledig verantwoorden van de tijdbesteding (Carcello e.a., 1996, p. 245; Malone en Roberts, 1996, p. 58; Otley en Bernard, 1996, p. 65; Donnelly e.a., 2002, p. 245; Donnelly e.a. 2003; Sweeney en Pierce, 2004, p. 779; Margheim, 2005, p. 33; PCAOB, 2008, p. 20). Hoewel het onvolledig verantwoorden van tijd geen rechtstreekse afbreuk doet aan de kwaliteit van assurance- of daaraan verwante opdrachten, leidt het tot een onjuiste voorstelling van zaken. Dit kan in een opvolgend opdrachtjaar leiden tot druk op de kwaliteit omdat de verantwoorde tijdbesteding een belangrijke factor is bij toekomstige afspraken over het honorarium (Otley en Pierce, 1996, p. 67).

\subsection{Overzicht van schendingen}

Accountantsorganisaties zijn verplicht een overzicht op hoofdlijnen te maken van schendingen door medewerkers van de bij of krachtens de artikelen 13 tot en met 24 van de Wta gestelde regels (hierna: schendingen) (Staatsblad, 2006b, art. 24 lid 1). Het overzicht moet de 'meest voorkomende of ernstige schendingen' bevatten (Staatsblad, 2006b, nota van toelichting). Deze vastlegging fungeert voor de AFM als graadmeter voor de werking van het stelsel van kwaliteitsbeheersing, voor de naleving daarvan en voor de wijze waarop accountantsorganisaties met schendingen omgaan. Het begrip 'medewerkers' omvat externe accountants en overige
Figuur 1 Schematische weergave overlapping normoverschrijdend gedrag, schendingen en incidenten

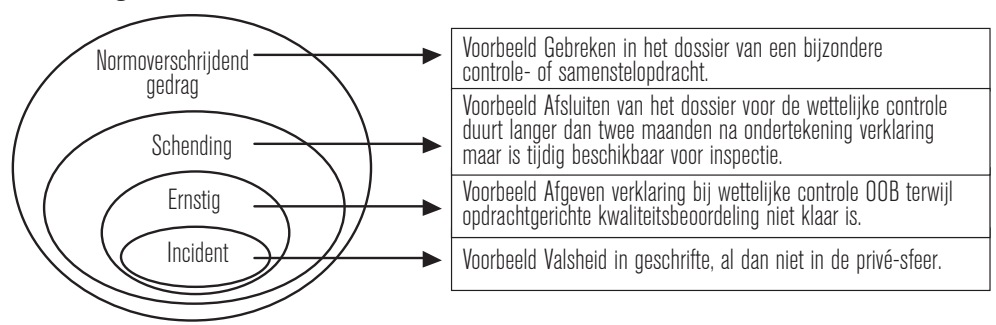

Tabel 1 Diversiteit in mogelijke schendingen ex Wta art. 13 tot en met 24

\begin{tabular}{|c|c|c|}
\hline $\begin{array}{l}\text { Voorschriften gekoppeld aan } \\
\text { de Wta }\end{array}$ & Voorbeeld koppeling ${ }^{8}$ & \begin{tabular}{|l|} 
Voorbeeld van schending die \\
voortvloeit uit deze voorschriften
\end{tabular} \\
\hline Bta & $\begin{array}{l}\text { Wta art. } 22 \\
\text { i.c.m. Bta art. } 21\end{array}$ & $\begin{array}{l}\text { Afgeven verklaring bij OOB, terwijl } \\
\text { opdrachtgerichte kwaliteits- } \\
\text { beoordeling niet is afgerond. }\end{array}$ \\
\hline $\begin{array}{l}\text { Verordening gedragscode } \\
\text { (VGC) }\end{array}$ & $\begin{array}{l}\text { Wta art. } 14 \\
\text { i.c.m. Wta art. 25, } \\
\text { Bta art. } 35 \text { en } \\
\text { VGC B1-240.3 }\end{array}$ & $\begin{array}{l}\text { Aanvaarden resultaatafhankelijke } \\
\text { beloning voor uitvoering van } \\
\text { wettelijke controle door een } \\
\text { externe accountant. }\end{array}$ \\
\hline $\begin{array}{l}\text { Verordening accountants- } \\
\text { organisaties (VAO) }\end{array}$ & $\begin{array}{l}\text { Wta art. } 21 \text { lid } 2 \\
\text { i.c.m. Bta art. } 34 \text { en } \\
\text { VAO art. } 9 .\end{array}$ & $\begin{array}{l}\text { Ontbreken van beleid bij de } \\
\text { accountantsorganisatie voor } \\
\text { uitvoering van periodiek intern } \\
\text { kwaliteitsonderzoek van afgeronde } \\
\text { wettelijke controles. }\end{array}$ \\
\hline $\begin{array}{l}\text { Verordening op de } \\
\text { kwaliteitstoetsing (VKT) }\end{array}$ & $\begin{array}{l}\text { Wta art. } 21 \text { lid } 2 \\
\text { i.c.m. Bta art. } 34 \text { en VKT }\end{array}$ & $\begin{array}{l}\text { Weigering van een accountants- } \\
\text { organisatie mee te werken aan } \\
\text { kwaliteitstoetsing van de wettelijke } \\
\text { controle. }\end{array}$ \\
\hline $\begin{array}{l}\text { Nadere voorschriften } \\
\text { onafhankelijkheid van } \\
\text { de openbaar accountant } \\
\text { (NVO) }\end{array}$ & $\begin{array}{l}\text { Wta art. } 14 \\
\text { i.c.m. Wta art. 25, Bta } \\
\text { art. } 35, \text { VGC B1-290.1 en } \\
\text { NVO par. } 4.1\end{array}$ & $\begin{array}{l}\text { Financieel belang in een wettelijke } \\
\text { controlecliënt gehouden door een } \\
\text { persoon die zich in de positie } \\
\text { bevindt van waaruit hij invloed kan } \\
\text { uitoefenen op de uitkomsten van } \\
\text { de controle. }\end{array}$ \\
\hline $\begin{array}{l}\text { Nadere voorschriften } \\
\text { permanente educatie } \\
\text { (NV PE) }\end{array}$ & $\begin{array}{l}\text { Wta art. } 14 \\
\text { i.c.m. Wta art. 25, Bta art. } \\
\text { 35, VGC A-130.7 en NV PE }\end{array}$ & $\begin{array}{l}\text { Afgeven accountantsverklaring bij } \\
\text { een wettelijke controle, terwijl niet } \\
\text { is voldaan aan de verplichting tot } \\
\text { permanente educatie. }\end{array}$ \\
\hline $\begin{array}{l}\text { Nadere voorschriften } \\
\text { controle- en overige } \\
\text { standaarden (NV COS) }\end{array}$ & $\begin{array}{l}\text { Wta art. } 14 \\
\text { i.c.m. Wta art. 25, } \\
\text { Bta art. 35, VGC A-130.7 } \\
\text { en NV COS }\end{array}$ & $\begin{array}{l}\text { Afgeven accountantsverklaring bij } \\
\text { een wettelijke controle, terwijl } \\
\text { deze controle niet is uitgevoerd } \\
\text { conform de controle- en overige } \\
\text { standaarden. }\end{array}$ \\
\hline
\end{tabular}

personen die werkzaam zijn bij of verbonden zijn aan de accountantsorganisatie en die zijn betrokken bij de uitvoering van wettelijke controles (Staatsblad, 2006b, art. 1 lid b). Het overzicht van schendingen bevat alleen schendingen die bekend zijn bij de in artikel 23, eerste lid, bedoelde persoon ${ }^{9}$ (hierna: compliance officer) of bij de personen die het dagelijks beleid van de accountantsorganisatie bepalen. De compliance officer en dagelijksbeleidsbepalers hoeven op basis van deze bepaling formeel dus niet actief op zoek 
te gaan. Indirect zijn zij echter wel verantwoordelijk voor een behoorlijk functionerend stelsel van kwaliteitsbeheersing en voor het integer functioneren van de accountantsorganisatie. Het is niet goed voorstelbaar dat zij deze verantwoordelijkheid kunnen uitoefenen als zij niet zorg dragen voor een deugdelijk signaleringssysteem van schendingen. Signalen voor schendingen kunnen hen bereiken vanuit diverse bronnen, zoals de opdrachtgerichte kwaliteitsbeoordeling, consultaties, klachten of periodieke dossierinspecties. Schendingen betreffen de artikelen 13 tot en met 24 van de Wta. Er bestaat een diversiteit in mogelijke schendingen vanwege de koppeling van de Wta met het Besluit toezicht accountantsorganisaties (Bta), met de verordeningen van de beroepsorganisaties en met bijbehorende Nadere Voorschriften (zie tabel 1).

De Wta en Bta zijn in 2008 gewijzigd (Staatsblad, 2008a en 2008b). Een situatie kan daarom nu kwalificeren als schending, terwijl dat niet het geval was toen de Wta en Bta in 2006 inwerking traden. Dit is relevant, bijvoorbeeld bij de vergelijking van het aantal schendingen per jaar. Zo dienen accountantsorganisaties sinds de wetswijziging in $2008 \mathrm{bij}$ overdracht van een wettelijke controleopdracht desgewenst hun opvolger toegang te verlenen tot alle relevante informatie over die controlecliënt. Doen zij dat niet, dan kwalificeert dit nu als schending van de Wta. Ook stelt het Bta nu eisen aan de groepsaccountant en is de definitie verruimd van een organisatie van openbaar belang (OOB). Dit laatste houdt bijvoorbeeld in dat voor een grotere groep controlecliënten een aangescherpt onafhankelijkheidsbeleid geldt en een verplichting bestaat tot het laten uitvoeren van een opdrachtgerichte kwaliteitsbeoordeling.

\subsection{Ernstige schendingen}

De Wta laat ruimte voor interpretatie bij het classificeren van schendingen als 'ernstig'. Een conceptuele interpretatie kan zijn: feiten die serieus afbreuk doen aan het doel van de geschonden regel (aard) of die belangrijke gevolgen hebben (impact). Een voorbeeld is de accountant die bij een OOB zijn verklaring afgeeft, voordat de opdrachtgerichte kwaliteitsbeoordeling is voltooid (Staatsblad, 2006b, art. 21). Deze handeling zet een kwaliteitsprocedure buiten spel en vergroot daarmee onnodig het risico dat eventuele onvolkomenheden niet tijdig aan het licht komen. Dit geldt bijvoorbeeld ook bij ondertekening van de verklaring door een RA of AA die niet is ingeschreven als externe accountant (Staatsblad, 2006a, art. 1 lid e). Ook kan een schending ontstaan wanneer de externe accountant een goedkeurende verklaring heeft verstrekt bij een jaarrekening die achteraf materieel onjuist blijkt. Had de accountant deze fout kunnen en moeten ontdekken? Zo ja, dan is in beginsel sprake van een ernstige schending; de controle heeft immers gefaald. Deze gedachte vertoont een parallel met de uitkomst van onderzoek naar frauduleuze financiële verslaggeving in China, waaruit blijkt dat de toezichthouder een sanctie oplegt aan een accountant die de fraude had moeten ontdekken, maar zijn plicht heeft verzaakt, terwijl de toezichthouder geen sanctie oplegt als hij de fraude niet had kunnen ontdekken, bijvoorbeeld vanwege opzettelijke vervalsingen en verhullingen (Firth e.a., 2005, p. 370). Het kwalificeren als schending van het gebrek aan controle op materiële fouten in de jaarrekening staat los van de vraag hoe de cliënt deze fout zal herstellen. Indien de fout materieel is, maar niet zodanig fundamenteel dat dit mededeling van het bestuur rechtvaardigt bij de Kamer van Koophandel ex 2: 362 lid 6 BW, blijft er sprake van een schending. Aan het doel van de controle is immers niet voldaan. Eventuele actie van de cliënt kan wel van belang zijn voor de opvolging van de schending.

Niet elk geval is zo ernstig is dat dit dwingt tot opname in het overzicht op hoofdlijnen. Een voorbeeld daarvan is de accountant die per abuis zijn dossier een dag te laat archiveert. ${ }^{10}$ De eis controledossiers uiterlijk twee maanden na ondertekening van de accountantsverklaring af te sluiten (Staatsblad, 2006b, art. 11 lid 4) heeft primair tot doel wijzigingen in het dossier te vermijden na afronding van de controle en te bewerkstelligen dat dossiers beschikbaar zijn voor inspectie, bijvoorbeeld door toezichthouders of interne kwaliteitsbewakers. In de Verenigde Staten geldt bijvoorbeeld een termijn van 45 dagen (PCAOB, 2004, art. 15). Archiveert de accountant per abuis het dossier van een wettelijke controle een dag te laat, dan zou men dat kunnen beschouwen als schending. Het hoeft echter geen serieuze afbreuk te doen aan het oorspronkelijke doel; het dossier is afgerond en beschikbaar voor inspectie. Opname in het overzicht met hoofdlijnen van schendingen is dan in beginsel niet nodig, tenzij blijkt dat dit soort schendingen frequent plaatsvindt.

\subsection{Incidenten}

Incidenten zijn 'strafbare feiten en wetsovertredingen die het vertrouwen in de accountantsorganisatie of in de financiële markten kunnen schaden' (Staatsblad, 2006b, art. 32 lid 1). Accountantsorganisaties dienen beleid te voeren ter vermijding van incidenten. Een voorbeeld daarvan is het zorgen voor voldoende personeel met de capaciteiten, bekwaamheid en gevoel voor normen en waarden die noodzakelijk zijn voor het uitvoeren van opdrachten conform vaktechnische richtlijnen en wet- en regelgeving. Doet zich desondanks een incident voor met ernstige gevolgen voor de integere uitoefening van de accountantsorganisatie, dan dient de organisatie dit onverwijld te melden bij de AFM. Ook moet de accountantsorganisatie passende maatregelen treffen, gericht op het beheersen van risico's die voortvloeien uit het incident en gericht op het vermijden van herhaling. Het maakt overigens niet uit wie bij de accountantsorganisatie het strafbare feit of de wets- 
overtreding heeft begaan. Het kan betrekking hebben op gedragingen van bijvoorbeeld personeelsleden, partners, bestuurders of commissarissen van de accountantsorganisatie.

\section{Aanleiding voor normoverschrijdend gedrag}

Om na te gaan hoe accountantsorganisaties normoverschrijdend gedrag kunnen vermijden, is het van belang kennis te nemen van mogelijke oorzaken, zoals budgetdruk, persoonskenmerken, organisatiebinding en leiderschapsstijl.

\subsection{Budgetdruk}

Verscheidene onderzoeken wijzen uit dat budgetdruk aanleiding kan vormen voor normoverschrijdend gedrag (Margheim, 2005, p. 24; Gundry, 2006, p. 44).Zo kan bij vaststelling van het honorarium voor de jaarrekeningcontrole spanning ontstaan tussen het streven van de controlecliënt naar lage accountantskosten, het maatschappelijk belang van een objectieve accountantscontrole en het belang van de accountantsorganisatie een cliënt te winnen of te behouden. Van Schaik (2003, p. 260) concludeert dat het honorarium van accountants niet beneden de differentiële kosten dient te liggen en dat zij bij vaste prijsafspraken een clausule dienen op te nemen dat zij meerwerk in rekening kunnen brengen indien de differentiële kosten achteraf hoger blijken te zijn dan het vooraf overeengekomen bedrag. Een afspraak met deze strekking gaat het ontstaan van normoverschrijdend door een vast controlebudget tegen. Overigens mag de accountant bij de ene cliënt best een lager honorarium in rekening brengen dan bij de andere cliënt, zolang deze maar niet beneden de differentiële kosten ligt, aldus Van Schaik. Dit betekent bijvoorbeeld dat een accountant bij onderbezetting een korting kan geven op het honorarium, mits deze korting niet zo hoog is dat dit ten koste gaat van de dekking op de differentiële kosten. Toepasselijk beleid van de accountantspraktijk kan het realiseren van een passend honorarium helpen waarborgen. Zo kan de accountantspraktijk instemming van een onafhankelijke tweede partner eisen met het overeengekomen honorarium en met de opdrachtvoorwaarden.

\subsection{Persoonskenmerken en organisatiebinding}

Donnelly e.a. (2003) onderzoeken onder accountants de neiging normoverschrijdend gedrag te tolereren en de rol van persoonskenmerken daarbij. ${ }^{11}$ De neiging tot het tolereren van normoverschrijdend gedrag blijkt onder meer samen te hangen met de mate waarin professionals ervaren dat de succesvolle uitkomst van een situatie het gevolg is van hun eigen inspanning. Hoe groter de indruk is dat eigen inspanning bijdraagt aan succes en hoe meer vertrouwen er is in de haalbaarheid van gestelde doelen, des te minder neiging er is tot het tolereren van normoverschrijdend gedrag. Dit is consistent met de uitkomsten uit eerder onderzoek van bijvoorbeeld Malone en Roberts (1996, p. 52). Dit betekent dat het nut heeft de naleving van professionele verantwoordelijkheden, waaronder het gedegen uitvoeren van de accountantscontrole, een belangrijke doelstelling te laten vormen bij prestatiebeoordeling, salariëring en promotie van medewerkers (IAASB, 2004, par. 11 lid b). Donnelly e.a. (2003) concluderen ook dat de intentie normoverschrijdend gedrag te tolereren, toeneemt als professionals zich voornemen de organisatie te verlaten. Deze bevinding is een generieke observatie die primair psychologisch van aard is.

Wanneer accountants voornemens zijn een functie te aanvaarden bij een controlecliënt kan overigens sprake zijn van een rationele bedreiging voor de onafhankelijkheid. Vandaar dat een accountant in dergelijke situaties zijn accountantspraktijk moet informeren (NIVRA, 2006b, art. 25). Hij mag in dat geval bijvoorbeeld niet langer deel uitmaken van het controleteam bij die cliënt en een collega met een hogere functie moet zijn recente controlewerkzaamheden beoordelen. ${ }^{12}$

\subsection{Leiderschapsstijl en organisatiemodel}

Volgens Otley en Pierce (1996, p. 68) speelt de leiderschapsstijl een belangrijke rol bij het ontstaan van normoverschrijdend gedrag. Zij verklaren dit vanuit de hiërarchische structuur binnen accountantspraktijken. De beoordeling die een ondergeschikte ontvangt van zijn leidinggevenden heeft een belangrijke invloed op de carrière binnen de accountantspraktijk. Hierdoor heeft het gedrag van de leidinggevende een belangrijke invloed op het gedrag van zijn ondergeschikte. Dit geldt ook op partnerniveau; grotere accountantspraktijken hebben in het belang van slagvaardigheid tussen partners onderling hiërarchische verhoudingen aangebracht, bijvoorbeeld door verschillende indelingen te onderscheiden (Jeppesen, 2007, p. 590). Accountantspraktijken opereren in een speelveld waar spanning kan ontstaan tussen winstoogmerk, het streven cliënten optimaal te bedienen en het naleven van professionele verantwoordelijkheden. Een te grote nadruk op cliënttevredenheid bij het bepalen van de beloning van accountants kan een te grote mate van welwillendheid stimuleren of leiden tot onvoldoende objectieve uitvoering van de assuranceopdracht (Matsumura en Tucker, 1995, p. 176; PCAOB, 2008, p. 21). Vandaar dat het nuttig is dat beleidsbepalers van een accountantspraktijk het belang van kwaliteit onderstrepen. Relevant in dit kader is bijvoorbeeld ook de conclusie van de PCAOB (2008, p. 21) dat het de objectiviteit kan aantasten van professionals met een vaktechnische rol, zoals degenen die opdrachtgerichte kwaliteitsbeoordelingen of consultaties verzorgen, wanneer zij worden beoordeeld door personen wier verantwoorde- 
lijkheid mede het laten groeien van de omvang en winstgevendheid van de accountantspraktijk omvat.

\section{Maatregelen}

Accountantsorganisaties moeten bij schendingen registreren welke aanpassing heeft plaatsgevonden in het stelsel van kwaliteitsbeheersing, welke maatregel zij hebben genomen jegens betrokken medewerkers en jaarlijks verslag uitbrengen aan medewerkers (Staatsblad, 2006b, art. 24 lid 2 en 3). ${ }^{13}$ De manier waarop accountantsorganisaties schendingen opvolgen kan van geval tot geval verschillen. Dit sluit aan bij de manier waarop chief accountants van de United States Securities and Exchange Commission (SEC) hun rol bij handhaving omschreven 'To be both creative and stimulative, to maintain a relationship with the profession that will encourage it to take action...to help professionals hold the line' (Sack, 1988, p. 77).

\subsection{Aanpassing in het stelsel van kwaliteitsbeheersing}

Bij de evaluatie of en zo ja welke actie nodig is om de ontstane situatie te herstellen, kunnen accountantsorganisaties incidentele schendingen onderscheiden van schendingen die frequent plaatsvinden. Een incidenteel ontbrekende opdrachtbevestiging kan de externe accountant mogelijk alsnog verkrijgen en vastleggen in het dossier. Bij andere schendingen kan het nodig zijn aanvullende controles uit te voeren of reeds uitgevoerde procedures alsnog te documenteren. Een schending kan ook betekenen dat de accountant terug moet komen op een reeds afgegeven verklaring, wat tevens vragen kan oproepen over de werking van het systeem van kwaliteitsbeheersing, bijvoorbeeld de opdrachtgerichte kwaliteitbeoordeling. Schendingen die frequent plaatsvinden geven doorgaans aanleiding interne procedures te heroverwegen. Ook de PCAOB (2008, p. 7) geeft aan dat tekortkomingen in de accountantscontrole een aanwijzing kunnen vormen voor zwakke plekken in het stelsel van kwaliteitsbeheersing bij de accountantspraktijk als deze tekortkomingen zich veelvuldig voordoen. Ontstaan zij door onbekendheid met het beleid dan kunnen accountantsorganisaties dit verhelpen door bijvoorbeeld vaktechnische training aan te bieden of ondersteuning. Soms is het een goed alternatief om de cliëntenportefeuille die de externe accountant bedient te heroverwegen, bijvoorbeeld bij een te grote diversiteit in typologie, branche of mate van regulering.

\subsection{Maatregelen jegens betrokken medewerkers}

Accountantsorganisaties kunnen overwegen disciplinaire maatregelen te treffen tegen betrokkenen bij een schending. Het is van belang daarbij een gevarieerd arsenaal aantal mogelijke maatregelen beschikbaar te hebben, zodat de accountantsorganisatie proportioneel kan interveniëren. Dit vergroot de geloofwaardigheid bij medewerkers van deze maatregelen, omdat de accountantsorganisatie deze kan variëren naar gelang de te corrigeren situatie. Geloofwaardige sanctiemogelijkheden hebben als positief effect dat hiervan al een kwaliteitsimpuls kan uitgaan, zonder dat de accountantsorganisatie deze hoeft aan te wenden. ${ }^{14}$

Aspecten die een rol kunnen spelen bij het beoordelen of en zo ja welke maatregelen nodig zijn na de constatering van een schending van de Wta zijn de ernst van de feiten, de verwijtbaarheid, het functieniveau van betrokkene, de wijze van herstel en de vraag of sprake is van recidive. Het passieve karakter van de verplichting schendingen te registreren pleit voor coulance bij het treffen van maatregelen als schendingen voortvloeien uit eigen melding van betrokkenen, bijvoorbeeld bij een verzoek tot vaktechnische consultatie. Dit om te vermijden dat accountants afzien van vaktechnisch overleg uit angst voor straf. Recidive, nalatigheid of het bewust niet melden van schendingen zijn echter voorbeelden van situaties die aanleiding vormen sancties te verzwaren.

Het verdient de voorkeur disciplinaire maatregelen te laten bijdragen aan het ontwikkelen van medewerkers, bijvoorbeeld een educatieverplichting. Vooral bij onbewuste overtredingen kan dit helpen herhaling te vermijden. Andere voorbeelden van sancties zijn een schriftelijke waarschuwing, het uitsluiten van betrokkene van bepaalde vormen van dienstverlening of een aanpassing van de beloning. Hoogendoorn (2002, p. 305) geeft twee stappen die accountantsorganisaties kunnen volgen bij het maken van een keuze of en hoe zij hun bevoegdheid aanwenden om invloed uit te oefenen op medewerkers. ${ }^{15}$ Stap 1 luidt: bepaal of betrokkenen niet weten aan welke eisen zij moeten voldoen, niet in staat zijn aan de eisen te voldoen of niet aan de eisen willen voldoen en stem de wijze van ingrijpen hierop af. Dit is van belang om met het juiste instrument op de situatie in te kunnen spelen. Immers, als de betrokken medewerker niet weet aan welke eisen hij moet voldoen, dan is dwang niet het juiste instrument. Een capaciteitsprobleem of gebrek aan expertise vereist een andere benadering dan het weigeren aan de vereisten te voldoen. Stap 2 luidt: stem de zwaarte van de bevoegdheid af op de te corrigeren situatie. Te zwaar ingrijpen kan negatieve consequenties hebben voor een functionele relatie tussen de accountantsorganisatie en de daaraan verbonden medewerkers.

Disciplinaire maatregelen zullen doorgaans zien op de externe accountant, vanwege zijn eindverantwoordelijkheid bij de wettelijke controle. Soms kunnen zij echter ook betrekking hebben op anderen uit het interne proces van kwaliteitsbeheersing. Zo zijn er voorbeelden uit de Verenigde Staten, waarbij de SEC kwaliteitsbeoordelaars een sanctie heeft opgelegd vanwege een ontoereikende uitoefening van hun taak (Mautz en Matusiak, 1988, p. 60). Dit illustreert de eigen verantwoordelijkheid van andere professionals met een rol in het interne proces van kwali- 
teitsbewaking. Voorbeelden daarvan zijn de tweede partner die op grote opdrachten fungeert als klankbord, de professional die de opdrachtgerichte kwaliteitsbeoordeling verzorgt of deskundigen die vaktechnische consultaties behandelen. Ook de $\mathrm{PCAOB}$ (2008, p. 21) benadrukt het belang van het handhaven van de eigen verantwoordelijkheid van professionals met een rol op het gebied van kwaliteitsbewaking. Hoewel deze professionals een eigen verantwoordelijkheid hebben in het proces van kwaliteitsbewaking, betekent dit overigens niet dat zij daarmee de eindverantwoordelijkheid van de accountant overnemen.

\subsection{Communicatie aan medewerkers}

Accountantsorganisaties moeten jaarlijks intern verslag doen van geconstateerde schendingen, getroffen maatregelen en de daaraan ten grondslag liggende overwegingen (Staatsblad, 2006b, art. 24). Dit verslag is bestemd voor medewerkers, zodat zij hiervan kunnen leren. De beleidsbepalers van de accountantsorganisatie onderstrepen zo het belang van kwaliteit. Dit is relevant gezien het effect daarvan op de interne bedrijfscultuur (IAASB, 2004, par. 10). Het verslag is anoniem; van naming and shaming is geen sprake. ${ }^{16} \mathrm{Het}$ verslag heeft daarom geen negatieve gevolgen voor de mate waarin een medewerker zich kan ontplooien binnen de accountantsorganisatie. Door het afgeven van signalen kan het bestuur van een accountantsorganisatie bevorderen dat een bedrijfscultuur ontstaat die is gericht op kwaliteit.

\section{Internationaal perspectief}

De Nederlandse wet- en regelgeving rond schendingen vertoont een parallel met internationale regelgeving, International Standard on Quality Control (ISQC) 1 van de IAASB (2004). Verschil in reikwijdte tussen de Wta en internationale standaarden voor kwaliteitsbeheersing heeft in Nederland echter geleid tot versnippering in weten regelgeving. Dit heeft als consequentie een complex stelsel van verordeningen en nadere voorschriften dat zich moeizaam laat onderhouden en het risico vergroot van onbedoelde overtredingen.

Verschil in eisen die wet- en regelgeving stellen aan het opvolgen van normoverschrijdend gedrag leidt voor accountantspraktijken die multinationale ondernemingen controleren tot complexe antwoorden op de relatief eenvoudige vragen wanneer sprake is van normoverschrijdend gedrag en hoe zij dit moeten beheersen. Omwille van transparantie en uitvoerbaarheid verdient het daarom de voorkeur Nederlandse aansluiting bij internationale regelgeving te maximaliseren door IFAC-regelgeving (International Federation of Accountants) integraal en woordelijk over te nemen en niet te versnipperen over verordeningen en nadere voorschriften. Deze aansluiting heeft ook als voordeel dat multinationale accountantsprak- tijken hun professionals niet langer hoeven op te leiden in twee afwijkende systemen.

De reikwijdte van de Wta beperkt zich tot accountantsorganisaties die wettelijke controles uitvoeren. ISQC 1 beslaat een breder spectrum, namelijk alle accountantspraktijken die assurance- en daaraan verwante opdrachten uitvoeren. Door de poging van de beroepsorganisaties het gat in reikwijdte te dichten, is een lappendeken ontstaan van her en der genomen maatregelen, verankerd in een complex stelsel van wetgeving, uitvoeringsbesluiten, verordeningen en nadere voorschriften. De Nederlandse wet- en regelgevers hebben overigens eisen die ISOC 1 stelt aan de opvolging van normoverschrijdend gedrag slechts gedeeltelijk overgenomen. Zo verplicht ISQC 1 ook opvolging te geven aan normoverschrijdend gedrag bij related services engagements (IAASB, 2004 par. 74-88), zoals samenstelopdrachten en opdrachten tot het uitvoeren van overeengekomen specifieke werkzaamheden. Deze eis is in Nederland niet opgenomen in nadere voorschriften, primair vanwege vereenvoudiging van regelgeving. Dit wijkt af van IFACvoorschriften en draagt niet bij aan het streven naar kwalitatief hoogwaardige dienstverlening. Het komt eveneens voor dat eisen die zijn overgenomen door de Nederlandse wet- en regelgever op afwijkende wijze zijn geïmplementeerd. Een voorbeeld daarvan is de introductie van begrippen zoals 'schendingen' en 'incidenten' waardoor inhoudelijke nuanceverschillen ontstaan.

\section{Conclusie}

Accountantsorganisaties beschikken over systemen gericht op kwaliteitsbeheersing. Als onderdeel daarvan maken zij een vastlegging van schendingen van de Wta door hun medewerkers. Schendingen kunnen aanleiding geven tot het herstellen van fouten of tot bijvoorbeeld het verbeteren van het kwaliteitsbeleid. Hiermee geeft de accountantsorganisatie blijk van zelfreinigend vermogen. Schendingen zijn een vorm van normoverschrijdend gedrag dat kan ontstaan door zaken zoals budgetdruk, persoonskenmerken of leiderschapsstijl. Vandaar dat een budget niet beneden de differentiële kosten dient te liggen en het mogelijk moet zijn meerwerk in rekening brengen. Ook is het belangrijk dat beleidsbepalers van de accountantsorganisatie nadruk leggen op het belang van kwaliteit bij prestatiebeoordeling, salariëring en promotie van medewerkers. Het jaarlijks intern verslag aan medewerkers van geconstateerde schendingen, getroffen maatregelen en de daaraan ten grondslag liggende overwegingen is eveneens een manier om aandacht te vragen voor kwaliteit. Disciplinair beleid kan helpen normoverschrijdend gedrag te vermijden. Een geloofwaardig beleid heeft namelijk als positief effect dat dit reeds een kwaliteitsimpuls kan geven, zonder dat de accountantsorganisatie deze mogelijkheid hoeft aan te wenden. Nederlandse wet- en regelgeving rond schendingen 
vertoont een parallel met internationaal gebruik. Verschil in de reikwijdte en diepgang van de Wet toezicht accountantsorganisaties ten opzichte internationale regelgeving heeft echter geleid tot een complex stelsel van verordeningen en nadere voorschriften van de beroepsorganisaties gericht op schendingen, incidenten en overige vormen van normoverschrijdend gedrag. Omwille van transparantie en uitvoerbaarheid verdient het daarom de voorkeur Nederlandse aansluiting bij internationale regelgeving te maximaliseren door IFAC-standaarden integraal en woordelijk over te nemen en niet langer te versnipperen. Deze aansluiting heeft ook als voordeel dat multinationale accountantspraktijken hun professionals niet langer hoeven op te leiden in twee afwijkende systemen.

Drs. A.R. Roos RA is director bij Deloitte.

\section{Literatuur}

- Carcello, J.V., D.R. Hermanson, H.F. Huss, Inappropriate audit partner behavior, views of partners and senior managers, Behavioral Research in Accounting, vol. 8, 1996, pp. 245268.

- Dassen R. en A.R. Roos (2007), De Wet Toezicht Accountantsorganisaties; een beschouwing, Maandblad voor Accountancy en Bedrijfseconomie, vol. 81, nr. 5, mei, pp. 174185.

Donnelly, D.P., D. O'Bryan en J.J. Quirin (2002), The perceived occurrence and acceptance of dysfunctional audit behavior, Journal of Forensic Accounting, vol. 3, pp. 245-252.

- Donnelly, D.P., J.J. Quirin en D. O'Bryan (2003), Auditor acceptance of dysfunctional behavior: an explanatory model using auditor's personal characteristics, Behavioral Research in Accounting, vol, 15, no. 1, pp. 87-110.

- Firth, M., P.L.L. Mo en R.M.K. Wong (2005), Financial statement frauds and auditor sanctions: an anlyses of enforcement actions in China, Journal of Business Ethics, vol. 62, pp. 367-381.

- Gundry, L.C. (2006), Dysfunctional behavior in the modern audit environment: the effects of time budget pressure and auditors' personality type on reduced audit quality practices, a dissertation submitted as a partial requirement for the degree of Bachelor of Commerce at the University of Otago, Dunedin, New Zealand, 2 October.

- Hoogendoorn, S.A. (2002), Toezicht in meervoud. Een bestuurskundig onderzoek naar het ontwerp en de werking van drie toezichtarrangementen, Den Haag: Boom Juridische uitgevers.

- International Auditing and Assurance Standards Board (2004), International Standard on Quality Control 1, Quality Control for Firms that Perform Audits and Reviews of Historical Financial Information, and Other Assurance and Related Services Engagements, www.ifac.org. - Jeppesen, K.K. (2007), Organizational risk in large audit firms, Managerial Auditing Journal, vol. 22, no. 6, pp. 590- 603.

- Margheim, L., T. Kelley en D. Pattison (2005), An empirical analysis of the effects of auditor time budget pressure and time deadline pressure, The Journal of Applied Business Research, vol. 21, no. 1, pp. 23- 35.

- Malone, C.F. en R.W. Roberts (1996), Factors associated with the incidence of reduced audit quality behaviors, Auditing: a journal of practice \& theory, vol. 15, no. 2, pp. 49-64.

- Matsumura, E.A. en R.R. Tucker (1995), Second partner review: an analytical model, Journal of Accounting, Auditing \& Finance, vol. 10, no. 1, pp. 173-200.

- Mautz, R.K. en L.W. Matusiak (1988), Concurring partner review revisited, Journal of Accountancy, vol. 165, no. 3, pp. 56-63.

- Nederlands Instituut van Registeraccountants (2006a), Verordening Gedragscode, 14 december, NIVRA, Amsterdam, www.nivra.nl.

- Nederlands Instituut van Registeraccountants (2006b), Verordening accountantsorganisaties, 14 december, NIVRA, Amsterdam, www.nivra.nl. - Otley, D. T. en B.J. Pierce (1996), The operation of control systems in large audit firms, Auditing: a journal of practice and theory, vol. 15, no. 2, pp. 65-84.

- Public Company Accounting Oversight Board (2004), Auditing Standard Nr. 3 - Audit documentation, June 9, www.pcaobus.org.

- Public Company Accounting Oversight Board (2008), Report on the PCAOB's 2004, 2005, 2006 and 2007 inspections of domestic annually inspected firms, release no. 2008-08, december 5.
- Roos, A.R. (2005), Indiensttreding van de accountant bij zijn controlecliënt, Maandblad voor Accountancy en Bedrijfseconomie, vol. 79 no. 5, mei, pp. 188-195.

- Roos, A.R. (2008), Kwaliteitsbeoordeling bij assuranceopdrachten, vreemde ogen dwingen,

Maandblad voor Accountancy en Bedrijfseconomie, vol. 82, no. 1/2, januari/februari, pp. 5-14.

- Sack, R. (1988), A journal roundtable discussion: Frank talk from former SEC chief accountants, Journal of Accountancy, vol. 166, no. 6, december, pp. 76-84.

- Schaik, F.D.J. van, (2003), Een toereikende vergoeding voor de jaarrekeningcontrole, Maandblad voor Accountancy en Bedrijfseconomie, vol. 77, no. 7/8, juli/augustus, pp. 254-260.

- Staatsblad (2006a), Wet van 19 januari 2006, houdende het toezicht op accountantsorganisaties (Wet toezicht accountantsorganisaties), no. 70, Den Haag, www.minfin.nl. - Staatsblad (2006b), Besluit van 16 augustus 2006, houdende regels ter zake van de uitvoering van de Wet toezicht accountantsorganisaties (Besluit toezicht accountantsorganisaties), no. 380, Den Haag, www.minfin.nl. - Staatsblad (2008a), Wet van 12 juni 2008, houdende wijziging van de Wet toezicht accountantsorganisaties en Boek 2 van het Burgerlijk Wetboek, ter implementatie van richtlijn nr. 2006/43/EG van het Europees Parlement en de Raad van de Europese Unie van 17 mei 2006 betreffende de wettelijke controles van jaarrekeningen en geconsolideerde jaarrekeningen, tot wijziging van de Richtlijnen 78/660/EEG en 83/349/EEG van de Raad, en houdende intrekking van Richtlijn 84/253/EEG van de Raad (PbEU L 157), no. 243, Den Haag, www.minfin.nl. - Staatsblad (2008b), Besluit van 23 juni 
2008 tot wijziging van het Besluit toezicht accountantsorganisaties en inwerkingtreding van de wet van 12 juni 2008 houdende wijziging van de Wet toezicht accountantsorganisaties en Boek 2 van het Burgerlijk Wetboek, ter implementatie van richtlijn nr. 2006/43/EG van het Europees Parlement en de Raad van de Europese Unie van 17 mei 2006 betreffende de wettelijke controles van jaarrekeningen en geconsolideerde jaarrekeningen, tot wijziging van de Richtlijnen 78/660/EEG en 83/349/EEG van de Raad, en houdende intrekking van
Richtlijn 84/253/EEG van de Raad (PbEU L 157), no. 244, Den Haag, www.minfin.nl.

- Sweeney, B. en B. Pierce (2004),

Management control in audit firms. A qualitative examination, Accounting, Auditing \& Accountability Journal, vol. 17, no. 5, pp. 779-812.

\section{Noten}

1 Accountantsorganisaties zijn ondernemingen of instellingen die bedrijfsmatig wettelijke controles verrichten, dan wel organisaties waarin zodanige ondernemingen of instellingen met elkaar zijn verbonden, als bedoeld in artikel 1, eerste lid, onderdeel a, van de Wet toezicht accountantsorganisaties, waaraan een vergunning als bedoeld in artikel 5 van die wet, is verleend, uitsluitend ter zake van de werkingssfeer van de Wet toezicht accountantsorganisaties.

2 Internationale standaarden voor kwaliteitsbeheersing bij accountantspraktijken die assurance- en daaraan verwante opdrachten uitvoeren, bepalen dat het kwaliteitsbeheersingssysteem van de accountantspraktijk gedragslijnen en procedures dient te bevatten, gericht op de volgende aspecten: a) de verantwoordelijkheid van de leiding voor kwaliteit binnen de accountantspraktijk, b) ethische normen, c) het aanvaarden en voortzetten van de relatie met de opdrachtgevers en van de specifieke opdrachten, d) het personeelsbeleid, e) de uitvoering van opdrachten en f) de bewaking (IAASB, 2004, par. 7). De Wta definieert een wettelijke controle als volgt: een controle van een financiële verantwoording van een onderneming of instelling ten behoeve van het maatschappelijk verkeer, die verplicht is gesteld bij of krachtens de in de bijlage bij de Wet toezicht accountantsorganisaties genoemde wettelijke bepalingen (Staatsblad, 2006a, art. 1 lid i). Het betreft onder meer de wettelijke controle van jaarrekeningen van lichamen die vallen onder artikel 2: 360 BW, dat zijn de NV, BV, onderlinge waarborgmaatschappij, coöperatie, stichting en vereniging die een onderneming in stand houdt. 3 Dit artikel hanteert de term normoverschrijdend gedrag. In internationaal perspectief wordt ook wel gesproken over inappropriate behavior, dysfunctional behavior, reduced audit quality behavior of quality threatening behaviour. Hoewel bij de invulling van betreffende termen sprake kan zijn van nuanceverschillen worden, zij in deze publicatie gehanteerd als equivalent.
4. De begrippen assurance- of daaraan verwante opdrachten omvatten onder meer controleopdrachten, beoordelingsopdrachten, opdrachten tot het samenstellen van financiële informatie en opdrachten tot het uitvoeren van overeengekomen specifieke werkzaamheden. Het begrip 'wettelijke controle' zoals gedefinieerd in de Wet toezicht accountantsorganisaties (Staatsblad, 2006a, art. 1 lid 1j) maakt onderdeel uit van het begrip 'assuranceopdrachten'.

5 Het onderzoek van Carcello e.a. (1996) is uitgevoerd in de Verenigde Staten via een steekproef onder senior managers en partners, werkzaam als controlerend accountant bij een van de elf grootste openbare accountantspraktijken.

6 Het onderzoek van Otley en Pierce (1996) richt zich op het systeem van interne beheersing bij drie van de toenmalige zes grote accountantspraktijken in lerland.

$\mathbf{7}$ Dit artikel beperkt zich tot assuranceopdrachten en opdrachten die daar aan zijn verwant om aan te sluiten bij een algemeen geaccepteerd internationaal raamwerk. Normoverschrijdend gedrag is ook mogelijk bij andere vormen van dienstverlening zoals advisering, of bijvoorbeeld in de privésfeer.

Bij de behandeling van de Wta gebruikt dit artikel de wettelijke term 'accountantsorganisaties'. Bij normoverschrijdend gedrag in algemene zin gebruikt het artikel de term 'accountantspraktijken', omdat normoverschrijdend gedrag meer omvat dan Wta-schendingen. De term 'accountantspraktijken' is afkomstig uit de Verordening gedragscode (NIVRA, 2006a) en omvat de wettelijke term accountantsorganisaties en het begrip 'accountantskantoren'.

8 Het in deze tabel gelegde verband tussen Wta artikel 13 tot en met 24 en de Bta, verordeningen of nadere voorschriften betreffen voorbeelden; in sommige gevallen zijn meer voorbeelden mogelijk van artikelen in de Wta die een dergelijk verband leggen.

9 Dit is een persoon binnen de accountants- organisatie die toeziet op de naleving van het stelsel van kwaliteitsbeheersing. Deze persoon is aanspreekpunt voor de dagelijksbeleidsbepalers en voor de AFM als toezichthouder. Het is een functie met een adviserende rol richting de dagelijksbeleidsbepalers van de accountantsorganisatie. Verder richt deze functie zich op het beheersen van de nalevingsrisico's en draagt daarmee uiteindelijk bij aan de beheersing van het reputatierisico van de accountantsorganisatie.

10 Een accountantsorganisatie dient ervoor te zorgen dat de externe accountant uiterlijk twee maanden na de ondertekening van de accountantsverklaring het controledossier heeft afgesloten (Staatsblad, 2006b, art. 11 lid 4).

11 Het onderzoek van Donnelly e.a. (2003) is uitgevoerd in de Verenigde Staten onder 205 accountants, werkzaam bij een van de tien geselecteerde accountantspraktijken. Onderzochte accountantspraktijken betreffen: alle toenmalige vijf grootste accountantspraktijken (Big 5) en een selectie van overige grote internationale accountantspraktijken, grote nationale accountantspraktijken, accountantspraktijken die in enkele staten opereren, accountantspraktijken die in één staat opereren en accountantspraktijken met slechts één vestiging. Donnelly e.a. (2003) richten zich in het onderzoek op drie vormen van normoverschrijdend gedrag: a) het paraferen van werkprogramma's zonder deze volledig uit te voeren, b) het niet geheel verantwoorden van de tijdbesteding en c) het wijzigen/herzien van controlewerk.

12 Zie Roos (2005) voor een meer uitgebreide uiteenzetting over bedreigingen en mogelijke waarborgen wanneer sprake is van een accountant die in dienst treedt van zijn controlecliënt. 12 De vastlegging van incidenten omvat ten minste de feiten en omstandigheden van het incident, de gegevens over degene of degenen die bij het incident zijn betrokken en de maatregelen die naar aanleiding van het incident zijn genomen (Staatsblad, 2006b, art. 33). Omdat incidenten strafbare feiten en wetsovertredingen betreffen die 
ernstige gevolgen voor de integere bedrijfsuitoefening hebben, zullen zij zich naar verwachting niet vaak voordoen. Paragraaf 4 behandelt daarom alleen de maatregelen gericht op schendingen. 14! Zie ook Hoogendoorn, 2002, p. 303. Er gaat geen kwaliteitsimpuls uit van bevoegdheden waarvan de verwachting bestaat dat de accountantsorganisatie deze niet effectief kan aanwenden, bijvoorbeeld vanwege disproportionaliteit. Hiervan zou sprake zijn wanneer de accountantsorganisatie alleen kan ingrijpen door het verbreken van de relatie met betrokkene, dat wil zeggen door ontslag of ontbinding van de partnerovereenkomst. $\mathbf{1 5}$ Het bestuurskundig onderzoek van Hoogendoorn (2002) richt zich op meervoudige toezichtarrangementen. De twee stappen die Hoogendoorn noemt, richten zich daarom op de relatie tussen de toezichthouder en degene die onder toezicht is gesteld. De door Hoogendoorn genoemde stappen zijn hier naar analogie toegepast op het disciplinair beleid van accountantsorganisaties gezien de parallel tussen de interne kwaliteitsbewaking binnen accountantsorganisaties en de rol van een toezichthouder. De term 'onder toezicht gestelde' is in onderhavig voorbeeld vervangen door 'betrokkene'. De essentie van de twee stappen die Hoogendoorn benoemt is echter ongewijzigd. Zie ook Dassen en Roos (2007), par. 3.1.2 waarbij het model van Hoogendoorn is uitgewerkt voor de toepassing van het handhavingsbeleid door de Autoriteit Financiële Markten richting accountantsorganisaties.

16 Naming and shaming is het openlijk aan de schandpaal nagelen en betreft een zeer zware sanctie (Hoogendoorn, 2002, p. 44). Het is daarom begrijpelijk dat accountantsorganisaties een grondige afweging zullen maken voor hiertoe over te gaan. 